\title{
Shared Places, Separate Spaces : Constructing Cultural Spaces through two National Languages in Finland
}

From, Tuuli

2017

From , T \& Sahlström , F 2017 , ' Shared Places, Separate Spaces : Constructing Cultural Spaces through two National Languages in Finland ' , Scandinavian Journal of Educational Research , vol. 61 , no. 4 , pp. 465-478 . https://doi.org/10.1080/00313831.2016.1147074

http://hdl.handle.net/10138/309187

https://doi.org/10.1080/00313831.2016.1147074

cc_by

acceptedVersion

Downloaded from Helda, University of Helsinki institutional repository.

This is an electronic reprint of the original article.

This reprint may differ from the original in pagination and typographic detail.

Please cite the original version. 
Shared Places, Separate Spaces. Constructing Cultural Spaces through two National Languages in Finland

\author{
Tuuli From $^{\mathrm{a}^{*}}$ and Fritjof Sahlström ${ }^{\mathrm{b}}$ \\ ${ }^{a}$ Institute of Behavioural Sciences, University of Helsinki, Helsinki, Finland \\ ${ }^{\mathrm{b}}$ Institute of Behavioural Sciences, University of Helsinki, Helsinki, Finland
}

*Corresponding author. Email: tuuli.from@helsinki.fi 


\begin{abstract}
:
Finland is a bilingual country with two national languages, Finnish and Swedish. The parallel school system for the national languages in Finland can be seen as an example of a spatial policy which aims to protect the significantly smaller Swedish language by maintaining the Swedish-language school monolingual. In this article the construction of linguistic and ethnic difference in educational discourse and practice related to the national languages in Finland is analyzed by using discourse analysis, feminist and post-structural theories. By analyzing ethnographic data and public debate we argue that discursive and material practices related to spatiality have a significant role in constructing difference and otherness in the Finnish school context. Essentialist categories are produced but also contested from the positions within the cultural spaces at school and in society at large.
\end{abstract}

Keywords: language; cultural space; difference; nation

Running head: Shared places, separate spaces 


\section{Introduction}

The recent debates on language issues in Finnish society seem to have concentrated on the field of sociolinguistics and linguistic anthropology (cf. Blommaert, Leppänen \& Spotti, 2012; Salo, 2012; Boyd \& Palviainen, 2015). Linguistic diversity has not received the same kind of attention in the field of cultural studies in education, despite the fact that language is a topical issue in many contemporary social movements, as can be seen in the ethno-linguistic conflicts of Eastern Europe. Recent changes in language policies in public education in Ukraine and Georgia, where Russian has been replaced with national languages or English, have made evident the central role of institutional education in both promoting and conversely limiting linguistic diversity. Hence, we argue that the analysis of language policy and educational spaces is necessary in order to understand and to promote linguistic diversity. Within the borders of a nation state, language is a profound marker of identity that functions as an administrative and cultural precondition of legitimate citizenship. Language frames the cultural space with and within which a nation is constructed to exist and regenerate its narrative and shared identity. (cf. Anderson, 2006; Rajander, 2010.)

National minorities have a special status in national policies, since they are minorities whose position is recognised and somewhat secured through cultural and linguistic policy-making. In a text published by the Council of Europe within the Framework Convention for the Protection of National Minorities the integration of national minorities is seen as central "for identifying and addressing... interethnic tensions, and thereby contributing to building and maintaining peaceful democratic societies in Europe.” (CoE, 2013). Apart from being recognised through language policies, a national minority is given a certain position in relation to the national narratives and images that are central in constructing the cultural spaces of the nation.

The national context of this article is Finland and the educational spaces of the Swedish-speaking Finns, who are also referred to as Finland-Swedes and SwedishFinns in other contexts. Swedish is one of the two national languages in Finland. In that regard the societal status of the Swedish-speaking national minority is different from the other national minorities, such as the Roma and the Sami, whose languages hold their status as minority languages. The Finnish nation state has been founded 
more or less on the idea of one nation and two languages, where Finnish and Swedish have been named as the legitimized languages of the national narrative. However, it can be argued that the two national languages have never really intertwined in creating a bilingual Finnish society, but have remained a source of controversy within language policy, despite of bilingualism being the constitutive principle of the nation since Finnish independence in 1917 (Ihalainen \& Saarinen, 2015, p. 38-39).

Compared to the dramatic changes in language policies in neighbouring countries, such as in the ethno-linguistic conflicts of Eastern Europe, however, the Finnish situation has been relatively stable.

The history of bilingual Finland dates back to the era when Finland was a part of the Swedish kingdom. Swedish inhabitants started spreading out to the Finnish peninsula during the $12^{\text {th }}$ and $13^{\text {th }}$ centuries, settling mostly in the coastal areas. Today, the Swedish-speaking population is still mainly concentrated along the coastline and in the country's biggest cities, such as Helsinki, Turku and Tampere. From a linguistic perspective Finnish and Swedish have coexisted as components of the Finnish nation state since the movement towards building it began in the $19^{\text {th }}$ century (cf. Engman, 1995; Saukkonen, 2013; Salo, 2012).

In Finnish society the division into Finnish- and Swedish-speaking institutions has been profound despite the relatively small percentage (5.5 per cent) of Swedishspeaking Finns. In addition to providing education and day care in Swedish, municipalities offering Swedish-speaking services for example in social and health care often have their own units alongside Finnish-speaking ones. One of the institutional structures creating spatial separation in terms of language in Finland is the parallel school system. According to the Finnish Basic Education Act, the two official language groups in Finland should be taught separately, which means that Finnish schools are monolingual. (Sahlström, From \& Slotte-Lüttge, 2013; Boyd \& Palviainen, 2015.) The Strategy for the National Languages of Finland declares that "a Swedish-language school cannot act as a language school because its task is to be an institution that passes on and creates Swedish language in Finland" (Tallroth, 2012, p. 14). Recently, the monolingual system has been questioned in new ways, however. Currently, there are approximately 35-45 monolingual Finnish-medium and Swedish-medium schools located in the same school buildings, yet functioning as 
separate units (Helakorpi, Ahlbom, From, Pörn, Sahlström \& Slotte-Lüttge, 2013). Proposals to increase the number of co-located schools are being discussed at the administrative level in many of the bilingual regions.

The public debate on school and language has been running since 2011 and has raised questions such as whether, in addition to co-located schools, there should be actual bilingual Finnish- and Swedish-medium schools in Finland, or whether a bilingual environment would be a threat primarily to the language minority. The ongoing debate on bilingual schools interrelates to a wider ideological debate about the foundations of a bilingual Finnish nation-state. A variety of Swedish-language cultural and political organisations, as well as the liberal Swedish People's Party, are involved in this debate, in order to maintain the secured position of Swedish as the second national language of Finland. (Boyd \& Palviainen, 2015; From, 2013; Karjalainen \& Pilke, 2012.) Due to the events in Finnish history discussed earlier in this article, the position of the Swedish language and the cultural autonomy of the Swedish-speaking population has always been a somewhat controversial topic in the Finnish societal debate (cf. Ihalainen \& Saarinen, 2015, p. 38). In recent years, after the rise of Finnish nationalist tendencies reflected in for example the Finns political party, the controversies of the language debate have culminated in questions of the obligatoriness of studying Swedish also in the less Swedish-speaking regions of Finland (cf. Salo, 2012, p. 32-33; Saukkonen, 2013).

Previous studies on combining both national languages in the context of Finnish education show that a strong dichotomy forms a basis for identity constructions both within societal discourses and in educational practices. Instead of aiming for a functional bi- or multilingual nation, cultural and linguistic strategies, including the Finnish legislation, seem to start with the premise of two separate, monolingual worlds. (From, 2013; Sahlström et al., 2013; Boyd \& Palviainen, 2015.) Finnish bilingualism might be described with Heller's (2006, p. 5) term parallel monolingualism, where languages are seen as autonomous systems instead of moulding into a hybrid. The overall discourse on the issues concerning the Swedish language in Finland has been characterized by linguistic dichotomies that have been visible, for example, in the way that bilingual education has been discussed in public during the past. Moreover, the legal status and practices concerning the two national 
languages indicate that the bilingual Finnish nation is constructed through a dichotomy of two separate languages and ethnic groups. Bilingual solutions are rarely available in any societal area and most societal actors, institutions and media function separately, legitimated in a hegemonic discourse, where monolingual institutions and thereby spatial isolation is meant to secure the minority language. This situation is crystallized in "Taxell's paradox", a statement named after a Finland-Swedish business manager and former minister Christoffer Taxell who initially, over three decades ago, explicated the necessity of monolingual solutions as a means of guaranteeing bilingualism. Taxell's paradox has gained a rather hegemonic position in the national discourse on bilingual solutions. It aims to address a concern of bilingual institutions turning into monolingual Finnish over time, as the majority language takes over.

This article aims to analyze and conceptualize the production of cultural spaces in the context of Finnish institutional education, in order to deepen an understanding of how differences related to language and ethnicity are constructed and embedded in schoolrelated discourses and practices. These discourses and practices are analyzed in relation to social categories and subject positions, through which spaces of segregation and inclusion are constructed. In particular, the study focuses on the abstract and material cultural spaces that are constructed in educational discourse and practice in a nation with a bilingual policy and a parallel school system for its two national languages. Taking into account the various positions constructed in a variety of discourses, we consider it to be valuable that the data was produced on multiple sites: ethnographic field recordings and interviews and media debate are combined in order to explicate the idea of a multidimensional cultural space.

\section{Theoretical framework - Space as a product of interrelations}

The concept of space and the idea of the spatiality of social life have become established in social science research and cultural studies (cf. Lefebvre, 1991; Massey, 1993, 2005; Harvey, 2004), even if the definitions in some contexts have been somewhat vague. In educational ethnographic research, space has been seen as a central concept in understanding the constructions of everyday life in schools and the different subjectivities and identities that are constructed in the school space (cf. 
Gordon, Holland \& Lahelma, 2000a, 2000b). In this article, we are making use of the notions of space found in feminist and poststructuralist research and cultural studies to analyze linguistic and ethnic difference-making and its consequences in educational settings in Finland. This spatial approach enables us to look at language and ethnicity as distinctive markers of identity in the context of institutional education, in order to understand their role in the formation of Finnish society as both a cultural space and a nation space that is a product of historical processes. (see Gordon et al., 2000a, 2000b; Rajander, 2010.)

In the field of cultural studies space, place and society have been conceptualized as intertwined and constituted through time. Space is not static or neutral, nor an empty container, but a set of interrelations which is continually being remade and never finished. Thus, the social and the spatial should always be conceptualized as inseparable. (cf. Massey, 1993, 2005.) This is also the starting point in our conceptualization and analysis of the construction of cultural space in educational discourse and practice. Moreover, the distinction between space and place is central for our analysis. Hadi-Tabassum (2006) has defined place as connoting a specific location and having material or territorial qualities, while space is relational and multidimensional. Yet, there is a social dimension to place as well; Gustafson (2006) sees places as social constructions, whereas Massey (2005) describes them as events. However, the relationship between space and place is tensional and mutually dependent (Hadi-Tabassum, 2006, p. 68-69). We do not see the concepts of space and place as parallel or somehow opposed, but overlapping and intertwined. Space, place and culture are often seen as integrated in a way that connects certain identities with certain places and cultures (e.g. Gupta \& Ferguson, 1992, pp. 7-8, Dovey, 1999, p. 16). In this article we argue that this assumption of the connection between identity and place is something that should be reconsidered, particularly in educational contexts.

Using the concept of cultural space, we understand space, place and culture as something that is constructed in educational policies, in everyday interactions and educational practices at school, and as something constructed in public discourses on education and society, and related to categories such as language, class and ethnicity. Moreover, we argue that these different levels of spatiality are interconnected (cf. 
Gordon \& Holland, 2003, p. 24) and that they construct cultural spaces, which in turn shape the discursive constraints of educational policy and practice. These discourses do take part in place-making as well, in the processes in which certain material or discursive spaces are given symbolic meanings.

In the field of post-structural educational research, and in particular ethnography, the spatial theorisation of Henri Lefebvre has provided insights into understanding difference in the school space. Of the different interpretations and analytical uses of the Lefebvrian theory we find particularly useful the work of Gordon, Holland and Lahelma, who have referred to space in the educational context as three-dimensional: physical, social and mental (Gordon et al., 2000a; cf. Lefebvre, 1991). Physical space refers to the school building in a material sense, its design as well as the students and teachers bodies populating the space. Pedagogical principles become a part of the physical school space as they are embodied in the school building - thus physical space is not simply 'already there'. Space is also social, in that it is created and reconstructed in educational discourse and practice. Finally, Gordon et al. present mental space as symbolic and imagined, as a place inhabited in mind. (ibid. 19.)

Hadi-Tabassum (2006) has applied the Lefebvrian triad in an analysis of bilingual school space. First, the conceptualization of space refers to the process through which the value of a particular space is created and given its social and political identity. By looking at space as practice Hadi-Tabassum refers to the material reproduction of spatial routines of the school day, such as getting in line for lunch. Finally, lived space refers to the space that is constructed by social actors in everyday life. (HadiTabassum, 2006, p. 67-68, cf. Lefebvre, 1991; Harvey, 2004.)

Power is a central concept, both in the poststructuralist framework as well, as in the spatial theorizations we are making use of in analyzing a bilingual school environment (Massey, 1993, 1994; Foucault, 1995). According to Dovey (1999, p. 19), power operates through social and spatial practices and is embedded in institutions. In this frame of reference we understand power as embedded in the production of space, as taking different forms in power relations between the actors impacting on the different spatial dimensions, enabling and constraining agency and creating boundaries. 


\section{Research data and analytical tools}

During a three-year project called Språkmöten (transl. language encounters) we observed the everyday life of a newly co-located high school in the Swedish-speaking area of Ostrobothnia, in western Finland, where Swedish is the dominant language of some of the municipalities. In 2011-13, during four periods of fieldwork, each lasting one or two weeks, we used video ethnography to observe the establishment of a new school campus inhabited by a Finnish-medium high school and a significantly smaller Swedish-medium high school.

The first period of fieldwork took place in the previous facilities of the schools during the fall semester preceding the move to the new, shared campus, while the second was carried out immediately after moving. In the later stages of the project we returned to the school on two more occasions.

The periods of fieldwork generated more than 200 hours of video data recorded during lessons, breaks and even in students' spare time. In both schools we had two voluntary focus students, who carried portable microphones throughout the school day and were observed with cameras by the project researchers from a varying distance. Moreover, these students were given video cameras and were asked to film their everyday life outside school. The students could thus decide themselves what they wanted to bring back to us. Most of this material consists of discussions and activities with family and friends. ${ }^{1}$ (cf. Rusk, Pörn, Sahlström \& Slotte-Lüttge, 2015.) Interviews with teachers and principals were conducted during visits to five colocated primary schools in different regions in Finland during the fall of 2012 (Helakorpi et al., 2013).

In this analysis we have combined the ethnographic data with newspaper material in order to contextualise our observations in co-located schools and make visible the discourses within which educational practice is constructed. The material on public discourse consists of 127 contributions published in four newspapers in Finland, between September 2011 and December 2014. It includes texts of various types and lengths written by various contributors: letters to the editor, articles, columns and editorials. Helsingin Sanomat (referred to as HS), the leading (highest circulation) daily newspaper in Finland and the Nordic countries, holds a rather hegemonic 
position in the Finnish debate. Hufvudstadsbladet (referred to as $H B L$ ) is the largest Swedish-language daily newspaper in Finland. Pohjalainen and Vasabladet are the largest Finnish- and Swedish-language daily newspapers of the strongly Swedishspeaking region of Ostrobothnia in Western Finland. All the material presented above has been analyzed in more detail in several articles and conference papers (cf. From, 2013, Helakorpi et al., 2013, Sahlström et al., 2013, Slotte-Lüttge, From \& Sahlström, 2013).

Here, the field data and the newspaper content have been analyzed using a poststructuralist discourse-analytical method with a focus on spatiality, which, as noted before, appears to be central to discourses relating to the education of the Swedishspeaking Finns. The approach aims at linking discourse and space in an analytical manner, where space is observed as produced and contested through discourses, in relation to material practices as well as to the symbolic meanings attached to them. The objective of this kind of a post-structuralist analysis, then, is to pay attention to the ways in which discourses function in enabling and producing certain forms of rationality (cf. St Pierre, 2000, pp. 485-487). This kind of awareness of the spatiality of social life, which Richardson and Jensen (2003) have called the cultural sociology of space, also stresses the construction of identity and belonging as both material and cognitive processes.

The previously presented theorizations on space draw mostly upon feminist and poststructural traditions concentrating on the construction of difference through a variety of mechanisms, such as otherization, naming and categorization. Apart from viewing categories such as ethnicity as being constructed through discursive practices, there are many concepts and categorizations related to language - such as mono- or multilingualism, mother tongue or even language itself - that can be considered as performative acts, socially constructed and thus questioned within a poststructuralist theoretical framework (Musk, 2010; cf. Butler 1999). The entire video data was sorted during the project Språkmöten and all the situations where explicit categorisation related to language or ethnicity emerged were put aside and transcribed into text. These texts were then read together with the interviews and newspaper data. Using this analytical framework, three themes emerged: the role of physical space in constructing social and mental space at school; how otherness is constructed in 
relation to a monolingual school space and finally, how a monolingual subject is constructed and, on the other hand, questioned in the data.

The role of the physical space of school in constructing cultural spaces

Traditionally, the Swedish-medium school in Finland has been considered a vital monolingual space for maintaining the Swedish language, this having been the main argument for spatial separation, particularly in education (cf. Sundman 2013). While looking at the described spatial division in a wider societal sense, new perspectives open up for understanding the turbulence caused by suggestions and plans to create bilingual schools. The idea of a bilingual school, be it a bilingual school building or a bilingual classroom, not only interrupts the division of the national languages but suggests a new kind of spatial structure that would call for reconstructing the cultural space of the Finnish school system and society at large. Resistance to this kind of a spatial reformulation has resonated in societal debates on national languages in Finland.

There are many [of us] who no longer want to be lame ducks forced to integrate into the majority culture but [want to] maintain our own speciality, ... we should strongly distance ourselves from even letting our children get their basic education in the same school buildings as the Finnish-speaking ones.

(Letter to the editor, HBL 19.6. 2012, translated from Swedish)

This excerpt manifests a discourse, in which a natural community of people is produced through a narrative of belonging (cf. Anthias 2002). This narrative in turn is applied for legitimating the need for a parallel school system. Spatial separation as a foundation for the parallel educational system becomes concrete in the ways in which the educational environments are conceived by the pupils and school staff. Even while operating in the same school buildings, the premise is to function as two individual units. This sets certain preconditions for using the school space and especially the shared parts of the building during the school day. As Gordon et al. (2000a) have noted, everyday life at schools is framed by time-space-paths. As in any school, the daily interaction in co-located schools is regulated by practices related to space and 
time, within facilities, whose design and use can be described as physically given or fixed. An example of temporal and spatial control and regulation are for instance breaks that can be either timed separately or overlapping. This applies to co-located schools that either have no, some or many shared activities. In an excerpt from an interview with the principal of a Swedish-medium school co-located in the same building as a Finnish-medium school, we can see how the mental, social and physical dimensions of the school space are interconnected. The school building has been designed and built for the purposes of both schools and a kindergarten, so that all three institutes and administration have their own wings built on to a connecting core, where the shared cafeteria is located.

Principal: but then it's naturally so that it's maybe a different thing when it's a new building where the division Swedish-Finnish has been made from the beginning that it's like really clear (.) that's what people mostly react to when they come here that it's really thought of but of course in such a way that there are nodes where you can meet (.) that in that regard the architect has really thought about these activities

Interviewer: do the pupils fully keep to their

Principal: for the most part yes (.) even when they have the possibility to meet they don't do it that much (.) then there's this group that has really good friends [in the other school] so they do meet and there's this area where they tend to be just there in the middle (.) that it has become so that they go to that area

(Interviews, 2012/2013)

The principal presents the school space as carefully planned by the architect in a manner where the material space and architectural solutions, such as spatial divisions or "meeting points", play a role in forming the social space of the school. According to the principal the main function of the building has been providing a clear division between the two language groups and nodes for formal or informal mutual activities. However, in this school's case the intentional spatial arrangements, the conceptualization of space is not strictly connected to the spatial control of the school, 
since the pupils are allowed to move around almost without restrictions. Nevertheless, the material space is shaping the social life and setting limits for action (cf. Arias, 2010); even if the pupils in principle would be able to contribute to an alternative formulation of their school space and meet each other outside the classes and other formal activities of the school, their spatial paths tend to follow the frameworks offered by the architect, where the main intention seems to be spatial separation during most of the curricular activities. The architectural solutions seem to promote separation over co-existence, since only the ones who already have good friends in the other school tend to meet each other in the "no-man's land" of the school building. In this way language as a marker of difference becomes spatially embodied through the spatial practices and conceptualization of language within the school space.

Within a monolingual spatial understanding and an essential understanding of a cultural and linguistic identity, with separate school buildings and language-based spatial regulation, shared spaces (school buildings, even schoolyards) can be viewed as a threat to the minority. According to Rönnlund (2013), identity processes always take place in a particular location and a particular social, historical and cultural context. The schoolyard plays a significant role in children's identity formations, while being a free space with multiple social relations and at the same time regulated and supervised (Rönnlund, 2013, p. 1-2; cf. Gordon et al. 2000a, pp. 137-138).

Even if a monolingual school space can be seen in some views as crucial to a small language minority (cf. Baker, 2011), critical consideration should be focused on how it dispels linguistic diversity within its boundaries and alienates some linguistic features as something that does not belong to "us" but "them". According to Massey (1994), defining a place in relation to a particular identity or community requires setting boundaries, which easily leads to the exclusion of some. She also points out that these boundaries around places hardly ever have anything to do with the reality of that particular location. An alternative interpretation would be to think of places as meeting places, articulated moments in the networks of social relations where a variety of identities get constructed. (Massey 1994, p. 25-29). 
Despite Massey's critique, the connection between place and identity is something that becomes concrete in the boundaries constructed on a co-located school campus. The following excerpt is a part of a video-taped conversation that a group of Finnishspeaking students ${ }^{2}$ are having on their way to their lessons in a corridor of a colocated school campus, where a relatively large Finnish-medium high school shares the campus with a significantly smaller Swedish-medium high school, whose classrooms are located along a separate corridor. However, the schools share many of the other classrooms and the students' activities are not spatially restricted.

Taina: I'll go this way (.) we're on Sweden's side

Niina: (laughing) we're on Sweden's side

Taina: we are on Sweden's side

Klaara: we just walked across the border

Taina: (in a terrified voice) no my [lesson] is it

Klaara: yes

Taina: it is

Niina: it's on Sweden's side

Klaara: shit (in Swedish)

(video recordings 2012, translated from Finnish)

In the conversation, the sharp spatial division of the school building forms a basis for defining the Swedish-speaking students as the distant others, to be situated on the other side of the border (cf. Hadi-Tabassum, 2006). While analyzing this conversation we as researchers paid attention to the tone the girls were using while talking about the boundary, making it sound like it was the border between the nations, by using a formal manner to make fun of the situation. By doing this the Swedish-speaking students were being positioned in another nation space, that of Sweden - the space the girls would then inhabit with their bodies and Klaara by using the Swedish language for swearing, skit. The pupils are also playing with the ambivalence of the Finnish-language expression "olla Ruotsin/ruotsin puolella”, which could be translated both as being on Sweden's (Ruotsin puolella) side, and as being on side of the Swedish language (ruotsin puolella), thus making Swedish "a foreign language" (cf. Halonen, Nikula, Saarinen \& Tarnanen, 2015, pp. 235-238). 
Even if the Finnish-speaking students keep joking about the border between two countries or language territories, the experienced cultural distance constructed in the physical school space could be the reason for emphasizing the boundaries and labelling the "Swedish side" as the wrong, uneasy place for the students to be in the Finnish-medium school.

Language, space and power become central in the spatially regulated everyday life of a bilingual school campus, where the pupils adopt the principles of spatial practices while constructing their social territories. Parts of the school become named as the property of a particular language group, such as the corridor of the Swedish-speaking ones or the lockers of the Finnish-speaking ones. When naming the places in this way and thus marking them as belonging to someone in particular, they are constructed as monolingual and ethnically homogeneous, as places of belonging or exclusion.

\section{A monolingual space and the other}

The discourses concerning the bilingual or Swedish-language arrangements in Finnish society often refer to the monolingual Swedish-speaking spaces as svenska rum, the Swedish space. In many contexts this explicitly monolingual space is seen as a necessity for the Swedish-speaking minority to stay vital and reproduce the cultural inheritance of a monolingual tradition. Also, the significance of identity is strongly present in the discourses related to Swedish space. From a spatial perspective, svenska rum can be considered both as a physical place and a societal mental space with a strong, exclusive identity (Massey, 1994, p. 8), in the same way as Gordon, Holland and Lahelma (2000a, p. 19) regard nation space as mental, yet something to be protected territorially. Svenska rum is often understood as materialised through physical autonomy - literally inside walls of one's own, with schoolyards shared with Swedish-speaking children only, with the Swedish-medium school forming a linguistically protected space. From this perspective, sharing the school building also interferes with the notion of svenska rum as a mental construct and identity formation. The following excerpt is an example of a discourse, which in an essentialist manner relies on a determinist connection between language, culture and identity.

In Finland, the cultural identity and community of the Swedish-speaking population only remain among its own people and language. Language and 
culture go hand in hand, which is something that those who with good intentions recommend a bilingual school don't seem to realise. I'm afraid that a mixed Finnish- and Swedish-medium school would put an end to the use of Swedish among the Finnish-Swedish pupils. And worst of all, the culture enriched by the social capital of our language minority would wither away, causing a loss for the whole country.

(Letter to the editor, translated from Finnish, HS, 3.11.2011)

In the excerpt, the separation of the two language groups is seen as neutral and unproblematic. Using language as a straightforward basis for division often carries an implicit understanding of other dimensions of difference as well, typically presented as a cultural issue. Here, culture itself is presented as a fixed entity, whose vitality can be measured in relation to class and in terms of social capital. In the letter to the editor, the assumption of consistency between language and culture, also known as the ethnolinguistic assumption, (cf. Blommaert, Leppänen \& Spotti, 2012) is explicated in the statement "language and culture go hand in hand". According to the contributor, the advocates of a bilingual school have ignored this connection as well as the risk that bilingual solutions would lead to the decay of both language and culture.

Physical separation and a monolingual school environment are presented as preconditions for the minority's existence, providing a concrete and abstract space for the minority language and culture to bloom and develop. In this discourse the construction of citizenship among the Swedish-speaking Finns is something that Yuval-Davis (2007) calls multi-layered citizenship. Rather than emphasizing the citizenship related to the Finnish nation state, the Finland-Swede cultural identity is attached to their membership of the Swedish-speaking community and its special status apart from the Finnish-speaking majority. The distinction between the minority and the majority culture is seen as a precondition for belonging to the nation, being a part of and enriching the Finnish nation space.

Yuval-Davis (Ibid.) also points out that not only are citizenships constructed on different layers at the same time but also within those layers by other intersecting social divisions, such as gender or class. However, the citizenship and cultural 
identity constructed within a distinct layer of citizenship, for example that of being a Swedish-speaking Finn, tends to homogenize that particular way of being.

The discourse on language and class is reflected in the following excerpt from a video recorded by a Swedish-speaking focus student. The student is having a kitchen-table discussion at home with her mother about the new co-located school campus and the other school options in the municipality. Prior to the beginning of the transcript, the student Johanna has argued that the reason for the fact that her new campus is populated by rowdy students, who throw food at each other and behave badly is that the Finnish-speaking school recruits low-ability students. However, her mother corrects this understanding, explaining that there is only one Finnish school of its kind in the city.

Johanna: well then I understand since I thought that I heard that [the Finnishmedium high school] is where all the people go who don't get in to other schools

Mother: no

Johanna: and that's why it's buzzing with

Mother: no I don't think so at all

Johanna: forgive me the word but "spongers" [miming apostrophes with fingers] other strange people

Mother: no but I don't think so at all (.) it would be (.) yeah

Johanna: you really do notice how similar we Swedish-speaking Finns are when you see how different all the others are (.) and you can pretty much tell whether people are Finns or if they are (.) you really can

Mother: mmm, well in a way for sure (.) kind of

Johanna: it is (.) or at least the ones who go to high school

Mother: mmm. (.) do you think that there are more (.) um (.) students in the Finnish school with a foreign (.) um (.) background Johanna: mm (.) for sure

According to Johanna, there is more diversity among the Finnish-speaking students in terms of social class and ethnicity than there is in the Swedish-speaking group. She had initially thought that many kids in the Finnish-speaking high school come from 
lower-income homes as was reflected in her choice of the Finnish word for a sponger, pummi. Her mother corrects her and tells that there are no other options for a high school in the area, thus everyone goes to the same school. ${ }^{1}$ Based on her previous knowledge, Johanna had questioned the quality of the Finnish-medium high school and labelled it as a school for "leftovers". She describes the Finnish-speaking school as "buzzing with spongers", which her mom tries to dismiss at first but soon partially agrees with. Johanna argues that being Finnish- or Swedish-speaking is embodied in a person's appearance in general and particularly in the school space. She suggests that being a Finn has something to do with a person's habitus and that she would also be able to tell if a person does not belong to the category of what se considers as "Finns", but to some other ethnic background. Interestingly, Johanna does not seem to include the Swedish-speaking Finns in the category of Finns. In this discourse the heterogeneity of the Finnish-medium high school is something that strengthens the uniformity of the Swedish-speakers, and discursively fixes their consistent identity.

The essentializing discursive practice, which Johanna involves herself in, can be referred to as groupism, a general and common tendency to take category-bound groups as basic constituents of social life and thus represent the world as "a multichrome mosaic of monochrome ethnic, racial or cultural blocs." (Brubaker, 2006, p. 7-8.) These blocs in turn are connected to essential identities, which function as pawns in identity politics. Everyday non-reflected and taken for granted interactional practices such as these easily lead to a non-reflective view of the deliberately simplified identity constructions, as well as difficulties in promoting equal practices in terms of linguistic and ethnic diversity among the "imagined community", as for example Anderson (2006) has described the sense of belonging together as a nation.

\section{Constructing a monolingual subject - and talking back}

Davies and Harré (1999) have used the concept of positioning to focus on how subjects are constituted and positioned through discursive practices and how these positions are negotiated by those who are taking part in the interaction. As for homogeneous places and spaces that are discursively constructed, they both enable 
the position of a monolingual minority subject and on the other hand hinder our likelihood of recognising linguistic diversity.

From the perspective of separate monolingual spaces, there is a group whose position is becoming more and more noteworthy in the current institutional context. The amount of families whose children use both national languages at home is increasing but bilingual children do not appear in the national statistics as individuals, since guardians in Finland are still able to choose only one official mother tongue for their children. As Boyd and Palviainen (2015) have also stated, one of the strands of the ruling discourse on bilingualism often emphasizes the benefits of two languages, and describes bilingual people as privileged instead of presenting this position as problematic. However, in many cases in our research data being bilingual brings along the experience of exclusion or of not wholly belonging to either of the language groups. In the institutional context being bilingual is experienced problematic particularly due to the lack of bilingual schools. For a bilingual person this means a compulsory choice between two monolingual institutions - and in consequence, giving up on the other.

As a bilingual person I often feel like I am floating in a void. Not 100 per cent at home in the Finnish-speaking world, not happy being placed in an artificial Finland-Swedish locker either. And there's nothing wrong with floating there and building my own bilingual identity that suits just me. The problem is that I was once forced to choose. I started in a Swedish-medium school, which was surely smart considering that my father and many of the children in the neighbourhood spoke only Finnish. But it still feels artificial that one should have to choose in a bilingual country. For bilingual children the choice is also about not choosing.

(A column in Hufvudstadsbladet, translated from Swedish)

Looking at dichotomous linguistic categories allows us to understand better how essentialist conception of identity functions as something that simplifies and excludes linguistic diversity. The contributor, above, uses the word "void" to describe the space left in between the two identity categories, the space where she, as a bilingual person positions herself within in the limits of the monolingual school institution. The 
exclusion in the case of the contributor has led to a situation where she has been able to construct agency in the space between, even if the experienced agency has not materialized within the monolingual institutional system. Despite the experienced agency, she still describes her identification as floating, which can also be understood as problematic, unstable and disconnected from what has been institutionally recognized. After all, bilingual agency is restricted to and compelled by the limited space between being monolingual Finnish or Swedish. Despite succeeding in constructing a flexible identity outside the two exclusive categories, the contributor does not relate the position of a bilingual person to freedom of choice in a positive sense. Instead, she describes this feature as being problematic since, from the perspective of a bilingual person, opening a door to one opportunity has always meant closing another.

As stated previously, bilingualism is a problematic position in relation to determinate, dichotomized identity constructions. It is also ambivalent, since in the societal discourse bilingualism tends to be seen purely as a matter of language, as a desired resource and an asset both on an individual level and from the perspective of national economic competitiveness (Baker, 2011; Pashby, 2013). However, in our research data bilingualism often gets constructed as a position that questions the spatial dichotomy, producing multiple and contradictory subjects (cf. Massey 1994, p. 6). There is a visible resistance, a refusal to be positioned in either of the monolingual lockers. This resistance can be referred to as talking back, a concept originally introduced by the feminist writer and social activist bell hooks (cf. Juhila, 2004). In this context, talking back can be understood as resistance to the given categorisations, questioning the hegemonic discourse around advantages of being bilingual and thus promoting the need for diverse educational places and spaces.

The resistance towards the subject positions enabled in a monolingual space can also be constructed in a context where bilingualism is not especially highlighted. In the following excerpt from a discussion recorded during the English lesson of the colocated Swedish-medium high school, a student called Fred is using a Finnish phrase in the middle of a conversation in Swedish, during which the students have been trying to find a definition for the English word obnoxious. 
Fred: [speaking in Finnish] feet on the ground head in the clouds

Daniela: [answering in Swedish] you're speaking the wrong language if you mean to communicate with me

Fred: [continues in Swedish, sarcasm in his voice] well you have lived in

Finland so I thought that

Daniela: oh did you think I know Finnish

Fred: yeah

Daniela: [laughing] so little you know about the world

In this instance, bringing the Finnish language to the Swedish space causes a reaction. For Daniela, Fred's use of Finnish in the Swedish school space appears as a statement she needs to answer by making another. Fred's aim was probably not to make a fuss by using the Finnish language in the first place, but rather to rely on the widely used and accepted practice of inserting Finnish words and phrases into spoken Swedish in Finland (cf. Haapamäki, 2008). Almost always, the use of interspersed Finnish does not lead to an explicit orientation to language. In this case however, we can see Daniela relying on a monolingual linguistic stance in her counter to Fred. Furthermore, Fred's subsequent response shows his ability to situate the counter within a linguistic discourse, and his readiness to provide an argument for his position, based on the notion of Finland as a bilingual space.

The interaction in the classroom shows how the different positions within the Swedish space are in flux and negotiable. The discursive practices through which the positions are constructed are multiple and contradictory (cf. Davies \& Harré, ibid.) The existence of the Swedish space enables Daniela to insist on Swedish only, whereas Fred's assumption of the possibilities and restrictions of agency relies on Finland as a nation space where Finnish language competency is assumed of everyone.

In our data, being bilingual is constructed as a position that has the potential to question the spatial dichotomy. However, in the data, a bilingual identity is constructed in a discursive space where the options are limited to the framework of a bilingual nation state, i.e. Finnish and Swedish, through which the access to citizenship is also legitimated. In reality the linguistic and cultural diversity in monolingual Finnish- and Swedish-medium schools is significant. About five per cent 
of pupils in both Swedish- and Finnish-medium schools nationwide have a mother tongue other than Finnish or Swedish, albeit with significant regional variation in these numbers. (cf. Westerholm, Lindberg \& Oker-Blom, 2014; Opetushallitus 2014). This group does not appear in the discourses on bilingual education in Finland. Rather, the dichotomous nation space manages to dispel the diversity that is not located on the bipolar axis of Finnish and Swedish, in both Finnish- and Swedishmedium schools.

\section{Concluding discussion}

We have argued that cultural space is produced and reproduced on various levels of social life: in educational policy, public debate as well as in the educational practices of everyday life and the lived school space. Cultural space both constrains and enables particular forms of public discourse on any topic, including education, as well as is being constrained and enabled by these discourses. Cultural space is also constructed through different spatial, material and abstract differentiations: through divisions of places, segregating "us" from "them". We have argued, that cultural space as an analytical concept ties together the political and practical, discursive and material dimensions of linguistic difference-making. Studying educational discourse and practice from a spatial perspective also offers the possibility of making visible the intersections within different layers of belonging (see Yuval-Davies, 2007).

In the title of this article, "Shared places, separate spaces" we have referred to the ways in which cultural spaces are constructed in co-located schools and in discourses on the national languages in education. Even if the physical school as a place and the national narratives were meant to be common and shared, cultural and linguistic identities are mainly constructed in separate cultural spaces rather than through belonging to the same national, cultural or educational space. Discussing bilingual educational solutions brings out this dichotomy, and in the everyday life of a colocated school the rather abstract division becomes concrete, through the spatial practices and social actors of the school.

We have argued that, in the context of education, enforcing the dichotomy through this kind of spatial policy appears problematic, since it tends to place pupils into given subject positions according to their school language. From this perspective, the 
contradictory positions of the growing number of children with two or more home languages are not recognised in the present system. Some categories, such as ethnicity or language, are considered more acceptable and natural or less political than other categorizations. These categories appear as merely reflecting reality, instead of reconstructing certain subjectivities (cf. Mietola, Lahelma, Lappalainen \& Palmu, 2005). According to our analysis this is particularly the case with language categories, which often, following a monolingual assumption, are oriented to as unambiguous and taken-for-granted. As Mietola and others suggest, it should be proposed as a feminist researcher's task to problematize and show the political in categories that are considered as neutral or apolitical. In this article we have problematized the categories related to language within the Finnish nation space and shown how they discursively intersect with differences such as ethnicity and social class in discourse and practice of schooling.

There is a contradictory pressure on educational and linguistic policy-makers to respond to the needs and demands of a linguistically indeterminate society. For the most part these policy discourses focus on concerns about language skills in terms of being able to communicate with "the other" or about improving national competitiveness by responding to the demands of Nordic collaboration. However, our analysis of the discourse shows that increasing weight is being added to the notion that linguistic diversity in contemporary Finnish society calls for solutions that would support flexible language use as well as recognize multi-layered belonging within linguistic categories.

\section{References}

Anderson, B. (2006). Imagined communities. Reflections on the origin and spread of nationalism. London: Verso.

Anthias, F. (2002). Beyond feminism and multiculturalism. Locating difference and the politics of location. Women's Studies International Forum. 25(3), 275-286.

Arias, S. (2010). Rethinking space: an outsider's view of the spatial turn. GeoJournal. 75(1), 29-41. 
Baker, C. (2011). Foundations of bilingual education and bilingualism. Bristol: Multilingual matters.

Blommaert, J., Leppänen, S. \& Spotti, M. (2012). Endangering Multilingualism. In: J. Blommaert, S. Leppänen, P. Pahta \& T. Räisänen (Eds.) Dangerous multilingualism. Northern Perspectives on Order, Purity and Normality. Basingstoke: Palgrave Macmillan, pp. 1-24.

Boyd, S. \& Palviainen, Å. (2015). Building walls or bridges? A language ideological debate about bilingual schools in Finland. In: M. Halonen, P. Ihalainen \& T. Saarinen (Eds.) Language policies in Finland and Sweden. Interdisciplinary and multi-sited comparisons. Bristol: Multilingual matters, pp. 57-89.

Brubaker, R. (2006). Ethnicity without groups. Cambridge: Harvard University Press. Butler, J. (1999). Performativity's social magic. In: R. Shusterman (ed.) Bourdieu: A Critical Reader. Oxford: Blackwell, pp. 113-128.

Council of Europe (2013). Compilation of the thematic commentaries of the advisory committee. Retrieved from: http://www.coe.int/en/web/minorities/publications.

Davies, B., \& Harré, R. (1999). Positioning: The discursive production of selves. In:

R. Harré \& L. Van Langehove (Eds.), Positioning Theory. Oxford: Blackwell.

Dovey, K. (1999). Framing places. Mediating power in built form. New York: Routledge.

Engman, M. (1995). Finns and Swedes in Finland. In: S. Tägil (Ed.) Ethnicity and nation building in the Nordic world. London: Hurst \& Company, pp. 179-216.

Foucault, M. (1995) Discipline and punish. New York City: Vintage Books.

From, T. (2013). “Kaksi kieltä, kaksi mieltä” Diskurssianalyyttinen tutkimus identiteettien rakentumisesta koulukielikeskustelussa. ["Two languages, two minds" A discourse analytical study on identities constructed in the debate about school and language] Master's thesis. Faculty of Behavioural Sciences. University of Helsinki. 
Gordon, T., Holland, J. \& Lahelma, E. (2000a). Making spaces. London: Macmillan.

Gordon, T., Holland, J. \& Lahelma, E. (2000b). Moving bodies/Still bodies:

Embodiment and agency in schools. In: L. McKie \& N. Watson (eds.) Organizing bodies. Policy, institutions and work. London: Macmillan, pp. 81-101.

Gordon, T. \& Holland, J. (2003). Nation space: The construction of citizenship and difference in schools. In D. Beach, T. Gordon \& E. Lahelma (Eds.) Democratic Education. Ethnographic challenges. London: Tufnell Press, pp. 24-38.

Gupta, A. \& Ferguson, J. (1992). Beyond "culture": Space, identity, and the politics of difference. Cultural Anthropology, 7(1), 6-23.

Haapamäki, S. (2008). Kunnon i sydfinlandssvenskt talspråk - ett fall av grammatikalisering? In: J. Lindström, P. Kukkonen, C. Lindholm \& Å. Mickwitz (Eds.), Svenskan i Finland 10. Bidrag från den tionde sammankomsten för beskrivningen av svenskan i Finland 12-13 oktober 2006. Nordica Helsingiensia. Institutionen för nordiska språk och nordisk litteratur, Helsingfors universitet, pp. 7286.

Halonen, M., Nikula, T., Saarinen, T., \& Tarnanen, M. (2015). 'Listen, there'll be a pause after each question“: A Swedish lesson as a nexus for multi-sited language education policies. In M. Halonen, P. Ihalainen, \& T. Saarinen (Eds.), Language Policies in Finland and Sweden. Interdisciplinary and multi-sited comparisons. Bristol: Multilingual Matters, pp. 220-246.

Harvey, D. (2004). Space as a key word. Paper for Marx and Philosophy Conference, 29 May 2004, Institute of Education, London.

Helakorpi, J. \& Ahlbom, I. \& From, T. \& Pörn, M. \& Sahlström, F. \& Slotte-Lüttge, A. (2013). Särbo, sambo, kämppis: rektorers och lärares erfarenheter av kontakt och samarbete mellan samlokaliserade finsk- och svenskspråkiga skolor [Apart, together, flatmates: principals' and teachers' experiences of collaboration between co-located Finnish- and Swedish-medium schools]. Research report from project Språkmöten. 
Heller, M. (2006). Linguistic minorities and modernity: a sociolinguistic ethnography. London: Continuum.

Ihalainen, P. \& Saarinen, T. (2015). Constructing 'Language' in language policy discourse: Finnish and Swedish legislative processes in the 2000s. In: M. Halonen, P. Ihalainen \& T. Saarinen (Eds.) Language policies in Finland and Sweden. Interdisciplinary and multi-sited comparisons. Bristol: Multilingual matters, pp. 2958.

Juhila, A. (2004). Leimattu identiteetti ja vastapuhe. [Stigmatized identity and talking back] In A. Jokinen, L. Huttunen \& A. Kulmala (Eds.) Puhua vastaan ja vaieta. Neuvottelu kulttuurisista marginaaleista. [To talk back and fall silent. Negotiating cultural margins] Helsinki: Gaudeamus, pp. 20-32.

Karjalainen, K. and Pilke, N. (2012). Samlokalisering, samarbete eller kanske sammansmältning? Analys av begreppet 'tvåspråkig skola' i en dagstidning. [Colocation, co-operation or perhaps assimilation? Analysis of the concept of 'bilingual school' in a daily newspaper] In N. Nissilä and N. Siponkoski (Eds.) Kielet liikkeessä, Språk i rörelse, Languages in Motion, Sprachen in Bewegung. VAKKI Publications 1. Vaasa, pp. 58-69.

Lefebvre, H. (1991). The production of space. Oxford: Blackwell.

Massey, D. (2005). For space. London: Sage.

Massey, D. (1994). Space, place and gender. Cambridge: Polity Press.

Massey, D. (1993). Politics and space/time. In M. Keith \& S. Pile (Eds.) Place and the politics of identity. London: Routledge, pp. 141-161.

Melander, H. \& Sahlström, F. (2010). Lärande i interaktion. [Learning in Interaction] Stockholm: Liber.

Mietola, R., Lahelma, E., Lappalainen, S. \& Palmu, T. (2005). Johdattelua kohtaamisiin kasvatuksen, koulutuksen ja tutkimuksen kentillä. [An introduction to encounters in the field of education, schooling and research] In: R. Mietola, E. 
Lahelma, S. Lappalainen \& T. Palmu (Eds.) Kohtaamisia kasvatuksen ja koulutuksen kentillä [Encounters in the field of education, schooling and research] Turku: Suomen kasvatustieteellinen seura, pp. 9-20.

Musk, N. \& Wedin, Å. (2010). Inledning [Introduction] In: N. Musk \& Å. Wedin (Eds.) Flerspråkighet, identitet och lärande [Multilingualism, identity and learning]. Lund: Studentlitteratur, pp. 9-22.

Opetushallitus (2014). Koulutuksen tilastollinen vuosikirja [The annual statistical report by the Finnish National Board of Education]. Koulutuksen seurantaraportit 2014:10.

Pashby, K. (2013). Related and conflated: a theoretical and discursive framing of multiculturalism and global citizenship education in the Canadian context. Doctoral thesis. University of Toronto: Canada.

Rajander, S. (2010). School and choice: An ethnography of a primary school with bilingual classes. Jyväskylä: Finnish Educational Research Association.

Richardson, T. \& Jensen, O. B. (2003). Linking discourse and space. Towards a cultural sociolocy of space in analysing spatial policy discourses. Urban Studies 40(1), 7-22.

Rusk, F., Pörn, M., Sahlström, F. \& Slotte-Lüttge, A. (2015). Perspectives on using video recordings in conversation analytical studies on learning in interaction. International Journal of Research and Method in Education. 38, 1, 39-55.

Rönnlund, M. (2013). Schoolyard stories: Processes of gender identity in a “children's place”. Childhood. DOI: 10.1177/0907568213512693. Published online 10 December 2013.

Sahlström, F., From, T. and Slotte-Lüttge, A. (2013). Två skolor och två språk under samma tak [Two schools and two languages under the same roof]. In L. Tainio and H. Harju-Luukkainen (Eds.) Kaksikielinen koulu - tulevaisuuden monikielinen Suomi. [Bilingual school - a future multilingual Finland]. Jyväskylä: Suomen kasvatustieteellinen seura, pp. 319-340. 
Salo, O.-P. (2012). Finland's Official Bilingualism - a Bed of Roses or of Procrustes? In: J. Blommaert, S. Leppänen, P. Pahta \& T. Räisänen (Eds.) Dangerous multilingualism. Northern Perspectives on Order, Purity and Normality. Basingstoke: Palgrave Macmillan, pp. 25-40.

Saukkonen, P. (2013). Erilaisuuksien Suomi [Finland of differences]. Helsinki: Gaudeamus.

Slotte-Lüttge, A., From, T. \& Sahlström, F. (2013). Tvåspråkiga skolor och lärande en debattanalys [Bilingual school and learning - a debate analysis]. In L. Tainio and H. Harju-Luukkainen (Eds.) Kaksikielinen koulu - tulevaisuuden monikielinen Suomi [Bilingual school - a future multilingual Finland]. Jyväskylä: Suomen kasvatustieteellinen seura, pp. 221-244.

St Pierre, E. A. (2000) Poststructural Feminism in Education. An overview. International Journal of Qualitative Studies in Education. 13(5), 477-525.

Sundman, M. (2013). Kaksikielisiä kouluja kaksikieliseen Suomeen? [Bilingual schools in bilingual Finland?] In L. Tainio and H. Harju-Luukkainen (Eds.) Kaksikielinen koulu - tulevaisuuden monikielinen Suomi. [Bilingual school - a future multilingual Finland]. Jyväskylä: Suomen kasvatustieteellinen seura, pp. 47-70.

Tallroth, P. (2012) Strategy for the National Languages in Finland. Prime Minister's Office Publications 7/2012. Retrieved from:

http://www.oikeusministerio.fi/material/attachments/om/toiminta/perusoikeudetjadem okratia/6F3CYgZBf/Kansalliskielistrategia_engl.pdf

Westerholm, A., Lindberg, M. \& Oker-Blom, G. (2014). Elevernas språkliga bakgrund år 2013 [Pupils linguistic background, year 2013]. Presentation in Finlandsvensk grundskolkonferens 3.4.2014.

Yuval-Davis, N. (2007). Intersectionality, citizenship and contemporary politics of belonging. Critical Review of International Social and Political Philosophy 10(4), $561-574$. 


\section{Notes}

1 Recording the conversations was particularly necessary during the project, since most of the material was analyzed using a conversation analytic method (cf. Melander \& Sahström 2010). Students were advised to switch off the microphone whenever they felt like they did not want to be recorded.

2All the informants named in this article are called by their pseudonyms. 